\author{
Szymon Klemba \\ mgr inż. \\ Zakład Dróg Kolejowych i Przewozów, \\ Instytut Kolejnictwa \\ sklemba@ikolej.pl
}

DOI: $10.35117 /$ A_ENG_17_02_03

\title{
Integrated tariff systems in transport - Poland and abroad, conclusions
}

\begin{abstract}
At the beginning, the idea of integrated tariff system in public transport as a part of integrated transport system is described. Based on a short review of studies on the preferences of passengers, which was made in Poland, the importance of tariff systems integration is explained, especially for the effective use of means of transport. Then four examples of tariff systems from Poland, and four from abroad are presented with an indication of strengths and weaknesses. As a conclusion from the analysis, main problems with integration of tariff systems in Poland are listed.
\end{abstract}

Key words: transport system, public transport, integrated transport

\section{Introduction}

Integration is understood as the process of forming a whole from a part [11] or otherwise, the process of forming a whole from fine particles [10]. According to various definitions, the system is a set of elements having a certain structure and a logically ordered whole [11], a coordinated set of elements [10], a set of elements, and relations between them [5]. The above definitions should result in an understanding of what an integrated passenger transport system should be. On the one hand, the infrastructure and vehicles of different modes of transport, on the one hand, and the broadly defined organization of transport processes for these modes of transport, also include elements such as the timetable and the tariff. The creation of an integrated transport system is based on the logical association of the above mentioned elements so as to make the transport processes of persons as efficient as possible.

The integration of the transport system should be carried out on two levels simultaneously: technical and organizational. Technically it is primarily the creation of common stops for various means of transport or convenient interchanges. In terms of organization, they are the coordination of timetables within one transport branch and between modes of transport (communication) and the creation of a common tariff system, referred to later in this article.

\section{Importance of tariff integration}

The weight of the issue of creating integrated tariff systems emphasizes the results of passenger preference surveys carried out in different cities in Poland, which can be concluded that the cost of travel is a very important factor determining the choice of means of transport.

For example, 76.7\% (the most important factor) of surveyed respondents in Mława [2] stated that to the more frequent use of public transport would encourage them lower ticket price. Among the people with a car as the second most important factor in the use of public transport (17\% of the respondents) in the Bydgoszcz-Torun agglomeration was a lower travel cost than by a car. Research for the city of Olsztyn [3] showed that the cost of the ticket is the main (apart from not having a car) as a factor encouraging the use of public transport, as indicated by $23 \%$ of respondents. On the other hand, in the case of studies conducted in the framework of the development of the so-called The transport plan for Rzeszów [6] and 
Gdynia [7] the most important postulates are directness and punctuality. These two demands are also associated with tariff charges. In addition to habits, the role, in this case, can also be related to the connection and delay with the cost of travel. In case of necessity of a change, travel time increases, which is important in case of time tariff, while in the case of zone tariff, which offers one-way tickets, the change means the need to validate a new ticket.

The above examples show that the shape of the toll tariff is a factor that can determine the degree of public transport. Encouraging as many users as possible to use public transport increases the efficiency of its use, given the fact that the cost of running a train or a tram is very close, whether it is traveling by a few or a few dozen people.

\section{Types of tariff systems}

The basic classification of types of tariffs covers [12]:

- uniform tariff,

- segmental tariff (sectional),

- zone tariff.

Uniform tariff is characterized by the same ride fee, regardless of the distance traveled, the most common means of transport thus no change. The change of means of transport results in the need to acquire another ticket, which can result in the demands of passengers as much as the number of direct connections. This tariff also discourages the use of public transport on short distances, where the single charge is high compared to the distance traveled.

The segmental tariff (sectional) assumes the division of the route into a specified number of sections [12]. Sections can be allocated based on the number of kilometers, the number of stops, or the travel time.

The zone (area) tariff is based on the division of the area being serviced into certain parts of its zones. These zones may vary in size and shape. On the basis of the knowledge of the systems in practice it can be stated that the zones may be concentric and ring-shaped (or parts thereof), or constitute a "polycentric" system, without a distinct central zone.

Basic knowledge of tariff types facilitates the analysis of practical examples, as it turns out that the most common cases are the mixed tariffs.

\section{Tariff integration in Poland - an outline of the problem, examples}

In Poland, there is no single example of an integrated transport system that would cover rail transport and bus transport (other than urban transport). Moreover, rail transport itself does not have an integrated tariff system, and the fare is not determined directly by the transport operator and depends on the carrier of the service used by the passenger. Interestingly, in the case of PKP Intercity, it is not possible to purchase a single ticket for interconnection between trains of the same category of carrier, which is an example of an extremely disadvantageous tariff (a passenger using the internet ticket distribution channel may suggest that there is no another opportunity, and for the pursuit of multi-page and often unacceptable tariff rules has no time).

It should be emphasized that the distribution channel should not be identified with the possibility or inconvenience of integrating tariff offers, as even the most innovative and modern technical solution will be useless without proper legal and organizational solutions, while on the other hand, tariff integration can operate without complicated and advanced IT tools, so they do not constitute a barrier to an integrated offer. The available IT tools should be used as they improve and facilitate the functioning of the system, but the technical issue should be secondary to the early system architecture.

One railway ticket system operated until the break-up of the state-owned PKP company into smaller parts. Next steps towards the disintegration of the tariff system, quite contrary to the trends existing in European countries, took place as a result of the 
establishment of several regional railway companies. There are many examples of partial integration of tariff systems, which is most often attributed to honoring a particular type of ticket by individual carriers, in parallel to the existing basic tariffs..

In this section, selected examples of tariff integration functioning in Poland are described. The author of the article has endeavored to make a critical analysis of the applied solutions, bearing in mind that every step towards tariff integration is an opportunity to draw constructive conclusions for the future that could be used in modifying existing or developing new tariff systems.

\section{Warsaw}

An interesting example of partial tariff integration in Poland is Warsaw and part of the metropolitan area. It includes transport by urban (and suburban) transport organized by the Municipal Transport Authority in Warsaw, and regional transport carried out by the company Koleje Mazowieckie sp. Z o.o. As a rule, two tariff zones were identified (see Figure 1.): No. 1 - city (area of the capital city of Warsaw) and No. 2 - suburban (outside Warsaw). Exceptions apply in the case of the accession of a given municipality to zone 1 . Within these zones, there is a tariff determined by the municipal transport operator, i.e. ZTM, which performs the services of urban transport operators: railway (Szybka Kolej Miejska w Warszawie), tram ( Tramwaje Warszawskie sp. Z o.o.) and bus (Miejskie Zakłady Autobusowe) or private (e.g. Mobilis Group, Michalczewski Ltd.). On the trains of the Mazowieckie Railway Company a tariff, kilometer, supplemented with various special offers are applied.

The mechanism of integration is extremely simple and readable: Koleje Mazowieckie undertook to honor a group of tickets issued by ZTM in Warsaw within the framework of adequate financial compensation. As a result, passengers with a daily or longer valid ticket are able to travel by all means of transport on the transport lines organized by ZTM and trains of the Mazovian Railways within the designated two tariff zones.

The simplicity of the solution does not equate to the convenience of the user. No ticket issued by the Koleje Mazowiecie, even periodically, even to a limited extent, is not honored in ZTM vehicles (except for exceptional cases, each time announced). This leads to bizarre situations, especially on the suburban railway line, where the same routes serve the trains of the Mazovian Railways and the Rapid City Railway in Warsaw. Passengers must know before traveling by train which carrier will travel because one-time ticket and monthly KM company cannot travel with SKM trains, while with one-time ticket ZTM cannot travel by train KM. This is contrary to the concept of urban or agglomeration railway, where it should be possible to travel by the first train in a given direction. Otherwise, the passenger may refuse to take into account the part of the offer which does not include his ticket, which makes him less attractive even though he is financed from the same source. 


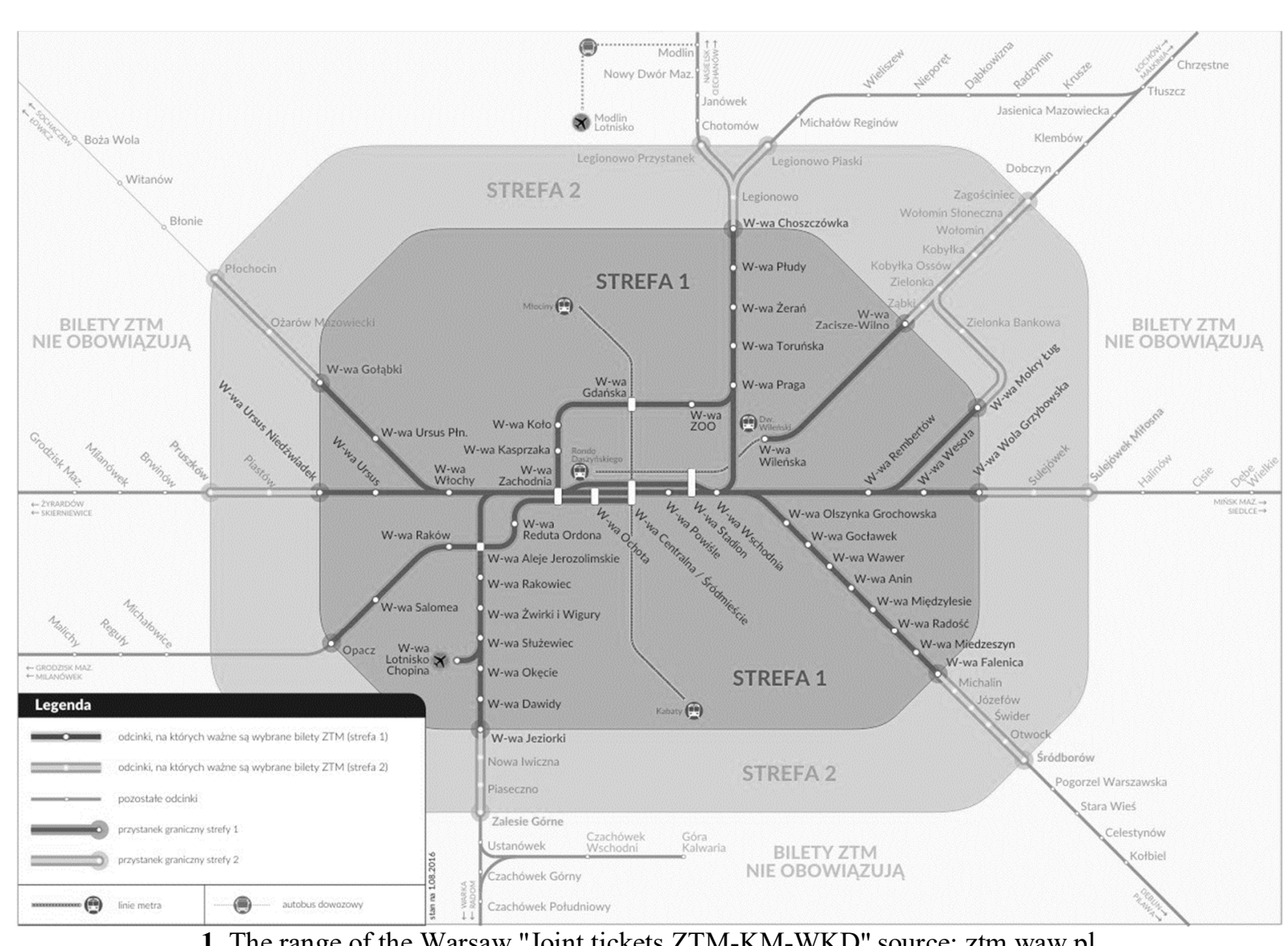

1. The range of the Warsaw "Joint tickets ZTM-KM-WKD" source: ztm.waw.pl

The Warsaw tariff system does not cover other carriers and lines of communication than those which carry out transport services on behalf of ZTM. This leads to a situation in which commercial lines are subsidized from public means of transport. On the other side of the transport chain, apart from Warsaw, in cities with public transport, there is no tariff integration, so a passenger traveling from Sochaczew to Warsaw in Sochaczew must have a separate ticket.

\section{Lódź}

Overview of urban and suburban transport tariffs in Łódź is important, as it is connected to suburban tram lines by neighboring centers. By 2010 there was a situation where two or three separate tickets for different transport organizers were to be validated when crossing the same tram line while crossing tariff boundaries. There were no tickets available for the entire trip. The situation has changed radically as a result of the signing of the interregional agreements on the introduction of the Łódź toll tariff on suburban lines (albeit with exceptions). In the later period (2014 - 2015), partial integration of urban transport with rail transport was introduced, but within a separate tariff system.

The tariff system on transport lines organized by the Łódź Road and Transport Administration covers two zones: urban (city boundaries) and suburban (outside the city limits). The city of Aleksandrów Łódzki is also covered by the city. Both time and period tickets can be used. Unfortunately, these tickets are not valid for public transport in the cities adjacent to Łódź, organized by these cities (Pabianice, Zgierz). This results in a passenger moving from a tram to a city bus to purchase a ticket from another transport organizer. In Pabianice, the passenger traveling by bus is purchasing a ticket issued by UM Pabianice, while traveling by tram - ticket ZDiT in Łódź, because "Pabianickie" tickets are not honored in Pabianice on trams. In the case of communication lines connecting Łódź with Zgierz, there 
are different tariff rules, depending on the communication line. Trams are issued by ZDiT in Łódź, bus number 6 is operated by Zgierz City Traffic Services Company and buses operated on line 51 operated by MPK Łódź are subject to tariff separation (at the border of the city you should cancel the ticket in the other city). As for periodic tickets, there are two "overlay" systems for the Łódź - Pabianice, and Łódź - Zgierz (30 or 90-day) tickets, which also include local carriers in Zgierz or Pabianice, although it does not include rail transport.

The integration of rail transport was introduced through the establishment of a new "institution" which is a Common Agglomeration Ticket, which only occurs in the form of a 30-day ticket. It covers the area of the Łódź agglomeration, which is served by trains of the Łódź Agglomeration Railway (see Figure 2). The basic WBA ticket includes public transport within the two ZDiT zones as well as trains of ŁKA and Regional Transport. Within the WBA, you can purchase a "WBA +" ticket with the option of using public transport organized by local governments. The main disadvantage of the offer is the operation of only 30-day tickets, as well as a high price, which does not provide a significant discount compared to the purchase of separate tickets. There is also no possibility to purchase a ticket to the area not covering Łódź, but only the "suburban".

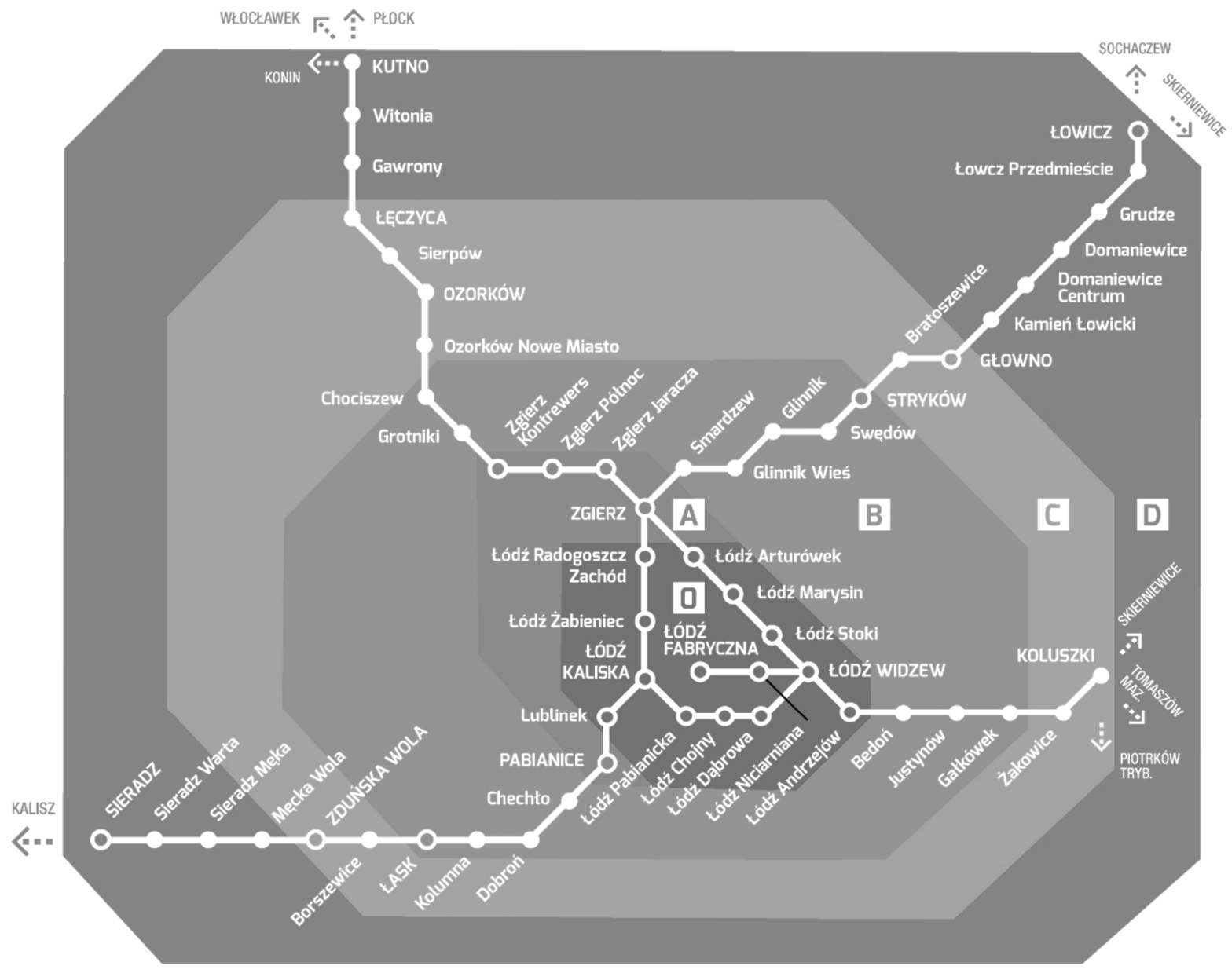

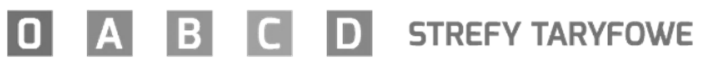

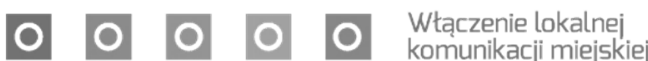

2. The scope of "Common Agglomeration Ticket", source: www.mpk.lodz.pl

To sum up the shape of the "Łódż" tariff system, it should be noted that there are several different interconnected tariff systems. This is a form of tariff integration which, however, should be referred to as an integrated tariff system. In contrast to the "Warsaw" 
system, it meets the basic needs (daily commuting to workplaces and learning in the period tickets) residents of the entire agglomeration.

\section{Tricity}

There are several public transport organizers and bus and railway operators operating in the Tricity and neighboring areas. Each city (Gdańsk, Gdynia, Wejherowo, Tczew) has its own ticket fare. Some cities are served by "neighboring" transportation boards. There is a separate railway tariff - PKP Szybka Kolej Miejska in Tricity. The multitude of organizers and operators operating in the Gdansk Bay Area has decided to set up a Metropolitan Transport Association of the Gdansk Bay, and with it, a separate tariff (Metropolitan Ticket) for travel, operating in parallel with the tariffs of individual organizers and carriers.

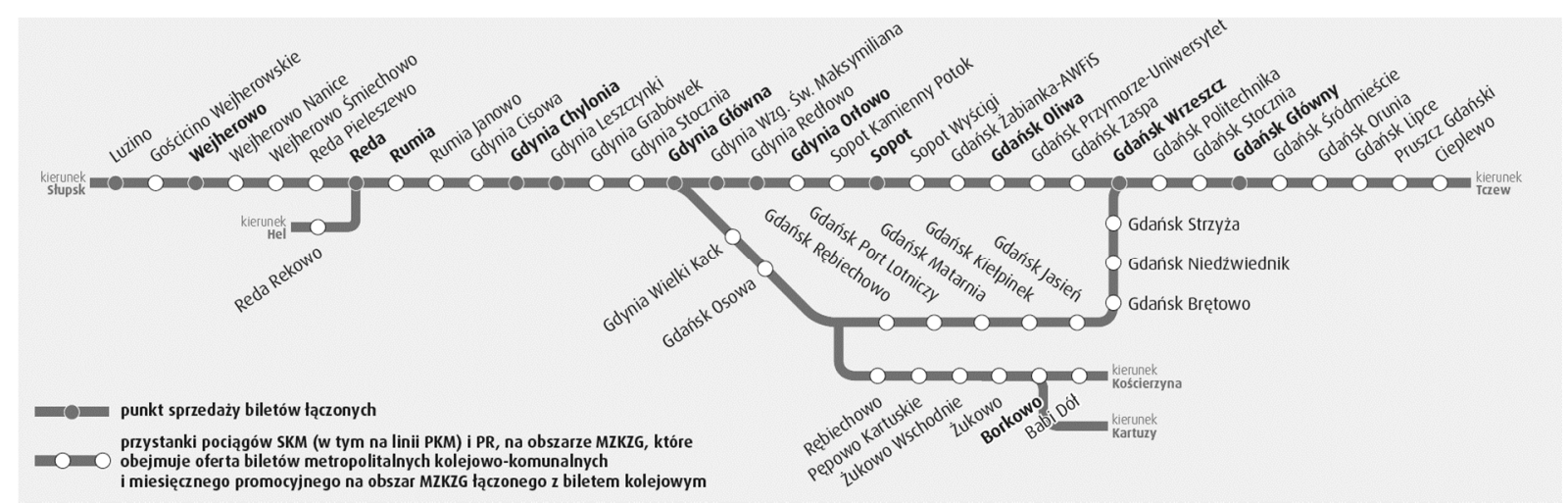

Fig. 3. Range of "Metropolitan Ticket" on the railway network, source: http://www.mzkzg.org

The area of the association covers the following territorial area: Gdańsk City, Gdynia City, Kolbudy Commune, Kosakowo Commune, Luzino Commune, Pruszcz Gdański Commune, Pruszcz Gdanski City, Reda City, Rumia City, Sopot City, Szemud Commune, Wejherowo Commune, Żukowo Commune.

There are 24-hour, 72-hour, 30-day / monthly tickets available (with or without train connections) within the "Metropolitan Ticket" tariff. There is also a one-way ticket, but it does not allow for transfer, so its integration function is doubtful (it does not include rail transport).

However, the tariff applies only on lines operated by ZKM Gdynia, ZTM Gdansk, MZK Wejherowo and in fast trains of the City Railways and Regional Transport. Other carriers (buses) operate outside of this system and are not covered by any form of tariff integration, which is a major disadvantage of this system. Another disadvantage is the lack of one-off tickets, as well as limited territorial coverage of the ticket (not covered by Kartuz and Tczew). On the other hand, as in the case of the "Łódź" WBA system, basic transport needs are met in the area of daily commuting as part of the Tricity periodic ticket as well as the "small Tricity","1.

\section{BiTCity (Bydgoszcz andi Toruń)}

"BiTCity" ticket is a tariff offer addressed to residents of Bydgoszcz and Torun traveling between these cities. Passengers have at their disposal one-off tickets (one train ride +60 minutes by public transport) or one month by public transport in Bydgoszcz and Torun as well as in regional trains running from Bydgoszcz to Torun and within these cities. The tariff is extremely simple and easy to read, however, it has a serious disadvantage: there is no one-

\footnotetext{
${ }^{1}$ The common name for the cities of Rumia, Reda and Wejherowo.
} 
way ticket available for commuting in one of these cities, train travel and public transport in the other city - this is only possible with monthly tickets..

This solution is difficult to call an integrated tariff system, due to its very narrow range - it is an offer mainly for people traveling daily between Bydgoszcz and Torun, while the rest of the suburban area around these cities is completely ignored..

\section{Foreign examples of integrated tariff systems}

This chapter discusses selected foreign examples of integrated tariff systems. The aim of the author was to present a differentiated approach to shaping these systems, as well as to highlight the complexity of the solutions adopted.

\section{Olomouc Region (zonal system - polycentric system")}

The country in the Czech Republic is the equivalent of the Polish province. Most of the Czech Republic has integrated transport systems covering all their areas. In the case of the Olomouc Region, there is a zonal system where zones are designated according to the administrative division. There are two types of zones that are distinguished in the tariff: zones that are larger cities in the country with municipal transport (the so-called zona with MHD) and others. The area of the Integrated Transport System of the Olomouc Region (Integrovanỳ Dopravní Systém Olomouckého Kraje, IDSOK) is shown in the diagram below (see Figure 4). IDSOK covers the whole country and small fragments of neighboring countries. Each zone is marked by a unique number.

Tariffs are defined by the document: "Tarif Integrovaného dopravního systému Olomouckého kraj". As a first step, the scope of the tariff is underlined:

- suburban transport on the lines in-country public road transport, operating within the system, and integrated trains of Czech Railways ${ }^{2}$ ( $\left.\breve{C D}\right)$,

- in urban transport in urban areas in cities: Olomouc, Prostějov, Přerov, Hranice, Šumperk, Zábř̀h.

An important element here are the lines of intra-country suburban communication (in Poland still colloquially referred to as "PKS", independently of the carrier). They are run on behalf of the transport organizer (so-called IDSOK Coordinator), which determines the timetable and the applicable tariff. These lines cover practically the entire area of the country (within the meaning of the Polish province) and function within the integrated tariff system. They are largely supported by private carriers, the list of which is set out in the fee document.

This is a practice totally opposite to that used in Poland, where almost all local bus transport was handled by private carriers, and the role of the organizer was limited to the role of the office issuing the regular transport license, with no significant impact on the tariff or timetable.

\footnotetext{
${ }^{2}$ The integration involves passenger trains (Os), accelerated (Sp) and fast trains (R).
} 


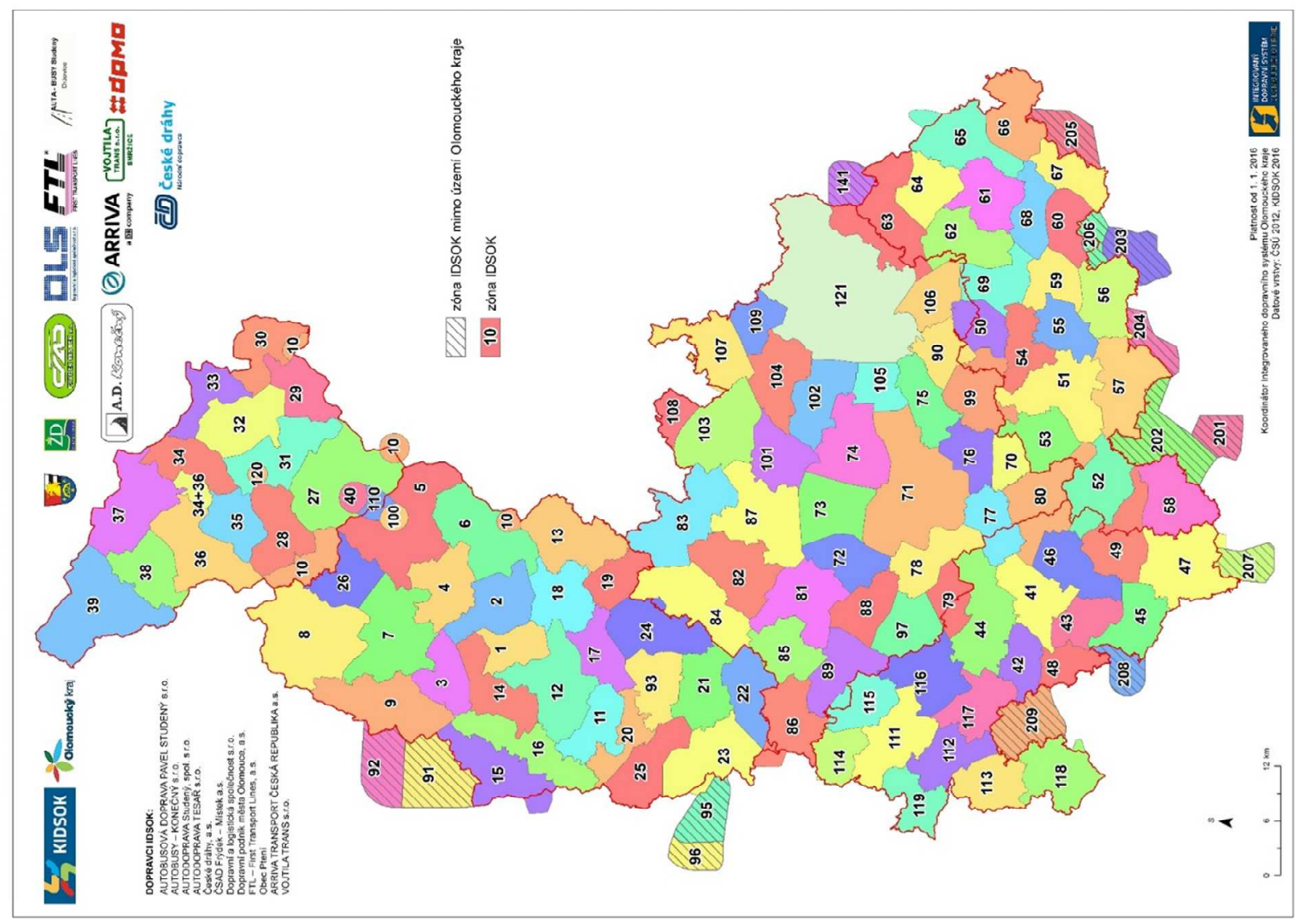

4. Range of tariff zones IDSOK, source: www.kidsok.cz

The basic IDSOK tariff offers the possibility to purchase one-time, weekly and monthly tickets. The toll is determined on the basis of the number of passenger zones. Two tables of charges have been defined, depending on whether the passenger crosses the Olomouc region (the Olomouc capital). The tariff allows you to travel through an area of 24 zones, except that there is no toll on the 18-zone ticket. The cheapest one way ticket, for one zone, costs 9 crowns (about $1.50 \mathrm{zl}$ ), which makes the offer very affordable. The validity of the ticket is limited in time, in the range of 40 minutes for one zone, up to 4 hours for the longest journeys. The ticket price for one zone varies according to whether it is a zone with or without public transport. Despite the apparent complexity of the system, the whole price list of normal tickets is in four tables (two tables, A and B, for the base price list, depending on the journey through Olomouc, table $\mathrm{C}$ for public transport, table $\mathrm{D}$ of charges applicable to Železnici Desná, example on Fig. 5.) which makes it extremely readable for the passenger. 


\begin{tabular}{|c|c|c|c|c|c|c|c|c|}
\hline \multicolumn{9}{|c|}{ Občanské a zlevněné (poloviční) jízdné v Kč } \\
\hline \multirow{3}{*}{$\begin{array}{c}\text { Počet } \\
\text { projetých } \\
\text { zón }\end{array}$} & \multirow{3}{*}{$\begin{array}{c}\text { občanské } \\
\text { jízdné } \\
\text { (obyčejné) }\end{array}$} & \multirow{3}{*}{$\begin{array}{l}\text { zlevnèné jízdné } \\
\text { (poloviční) }\end{array}$} & \multicolumn{2}{|c|}{ ednotlivé } & \multicolumn{2}{|l|}{7 denní } & \multicolumn{2}{|c|}{ Měsíční } \\
\hline & & & \multicolumn{2}{|c|}{$\begin{array}{c}\text { časová platnost } \\
(\mathrm{min})\end{array}$} & \multirow{2}{*}{$\begin{array}{l}\text { občanské } \\
\text { jízdné } \\
\text { (obyčejné) }\end{array}$} & \multirow{2}{*}{$\begin{array}{c}\text { zlevněné } \\
\text { jízdné } \\
\text { (poloviční) }\end{array}$} & \multirow{2}{*}{$\begin{array}{l}\text { občanské } \\
\text { jízdné } \\
\text { (obyčejné) }\end{array}$} & \multirow{2}{*}{$\begin{array}{l}\text { zlevněné } \\
\text { jízdné } \\
\text { (poloviční) }\end{array}$} \\
\hline & & & $\begin{array}{l}\text { prac. } \\
\text { dny }\end{array}$ & $\begin{array}{l}\text { ostatní } \\
\text { dny }\end{array}$ & & & & \\
\hline 1 & 9 & 4 & 40 & 60 & 70 & 35 & 230 & 115 \\
\hline 2 & 16 & 8 & 45 & 60 & 140 & 70 & 440 & 220 \\
\hline 3 & 22 & 11 & 60 & 60 & 202 & 101 & 630 & 315 \\
\hline 4 & 28 & 14 & 75 & 75 & 256 & 128 & 810 & 405 \\
\hline 5 & 35 & 17 & 90 & 90 & 312 & 156 & 990 & 495 \\
\hline 6 & 42 & 21 & 105 & 105 & 373 & 186 & 1190 & 595 \\
\hline 7 & 48 & 24 & 120 & 120 & 429 & 214 & 1370 & 685 \\
\hline
\end{tabular}

5. Price Chart A (fragment) of the IDSOK system, source: www.kidsok.cz

IDSOK's advantage is the possibility of passing on one ticket by train, local bus and public transport, with a very clear and simple tariff, throughout the Olomouc Region (Olomouc Region).

\section{Prague and Central Bohemia (zonal system - coaxial system)}

The Prague Integrated Transport System (IDS PID) covers an area within a radius of 40-65 $\mathrm{km}$ from Prague, in Central Bohemia (Středočesky Kraj). As part of the system, there are 155 suburban bus lines (not counting the urban transport system in Prague and other cities, which comprise another 175 lines), serviced by several bus carriers. Within the system, there are 33 railway lines, 34 tram lines, 3 metro lines, 5 ferries and a cable and railway line in Prague. The map of the railway lines that are part of the system and its range is shown in the diagram below (see Figure 5).

The area of the system is divided into 6 bands in the form of rings numbered 1 to 7 , centered around the zones of the city of Prague marked P, O, B. The zones 5, 6 and 7 are ring fragments, the remaining ones have a full ring shape around the central part of the city of Prague. Within the integrated transport service zones 1-6 (in zone 7 there is no railway line). 


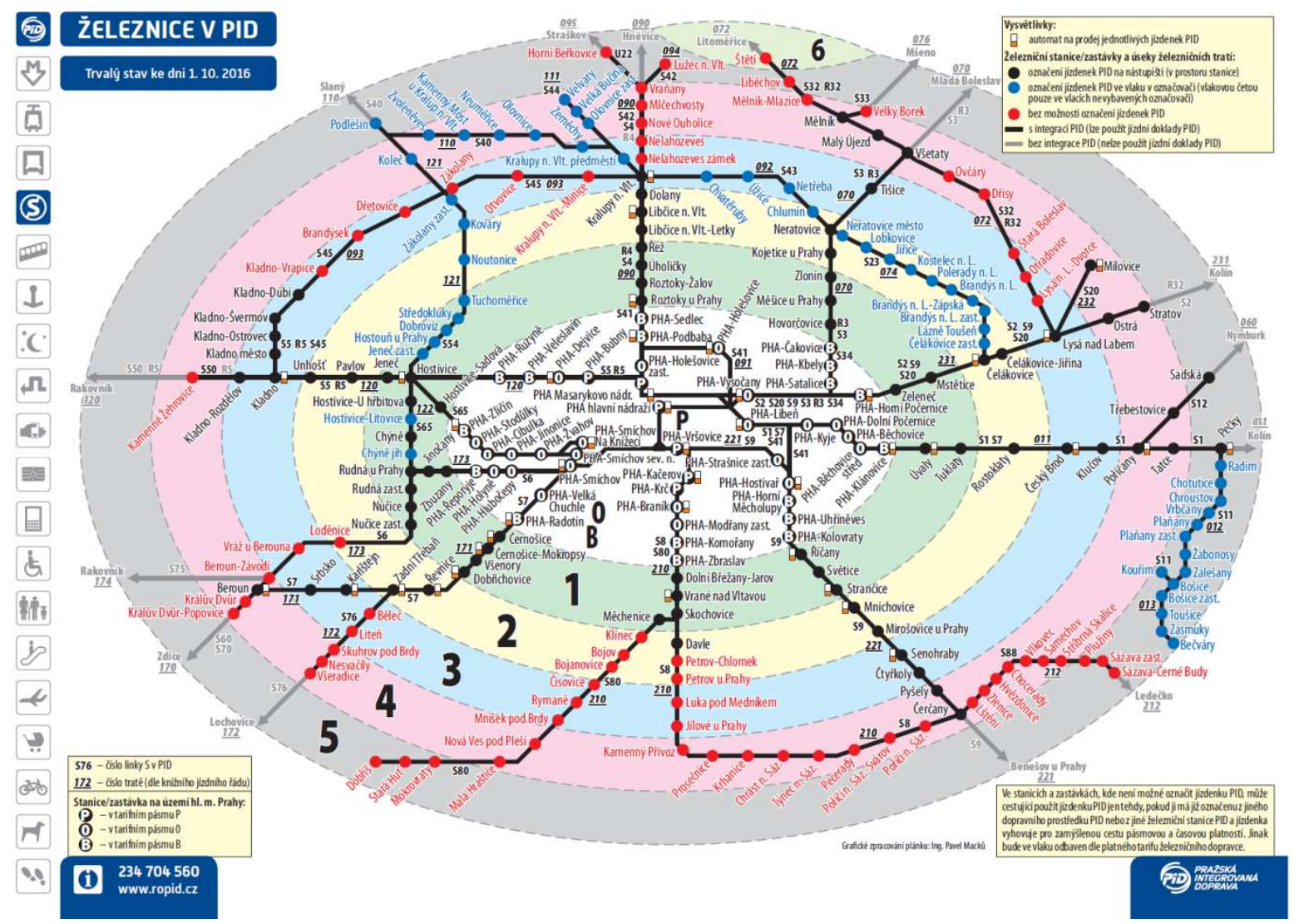

5. Range of PID tariff zones, source: [9], status on 1.10.2016 r.

Passengers are offered both integrated and one-off tickets. There are 12 types of disposable tickets available, depending on the number of zones (from 2 to 11) and the validity period (from 15 minutes to 24 hours). Tickets valid for 2 and 3 zones do not apply in public transport in Prague, the rest are valid in all modes of communication - the Prague area is counted as four tariff bands: one double zone ( $\mathrm{P}$ - public transport and the other in the center) (O - railway stations around the center, B - railway stations in the border area of the city).

Periodic tickets are available in two variants: monthly and quarterly, with 1 to 8 zones. Interestingly, they do not apply in zone P, i.e. in public transport in Prague. Passengers traveling to and from the Czech capital and Prague public transport are obliged to purchase two tickets: urban $\mathrm{P}, \mathrm{O}$ and $\mathrm{B}$, as well as an integrated zone for non-urban areas. Ticket prices are calculated so that this solution cannot be felt as more expensive. When analyzing the Praha-Hostovice report (band 1) the passenger must purchase: a one-month ticket for transport in Prague (zones P, O, B), which costs 550 crowns, and a ticket integrated into one zone for 300 crowns (total 850 crowns), which is slightly less than the ticket for 4 zones according to the integrated tariff (920 crowns).

The solution is simple and user-friendly. Despite the lack of full integration of the urban zone in the fare range of tickets, the solution adopted can be considered as beneficial for passengers. According to the organizer of the transport, this solution is explained by the more intensive service of the Prague part than the other region of Central Bohemia, so the means of the "urban" periodic tickets cover the functioning of public transport in Prague.

\section{The zone system - Bratislava}

The Integrated Transport System of Bratislava and the Bratislava Region (abbreviated as IDS BK) covers Bratislava and the Bratislava Region (in Poland it will be called a province). The area covered by the system is divided into 10 ring zones surrounding the central zone 
consisting of two zones (Nos. 100 and 101). No ring is closed due to the characteristic location of Bratislava in relation to the borders with Austria and Hungary. In addition, the rings are divided into smaller sections (see Fig. 6.).

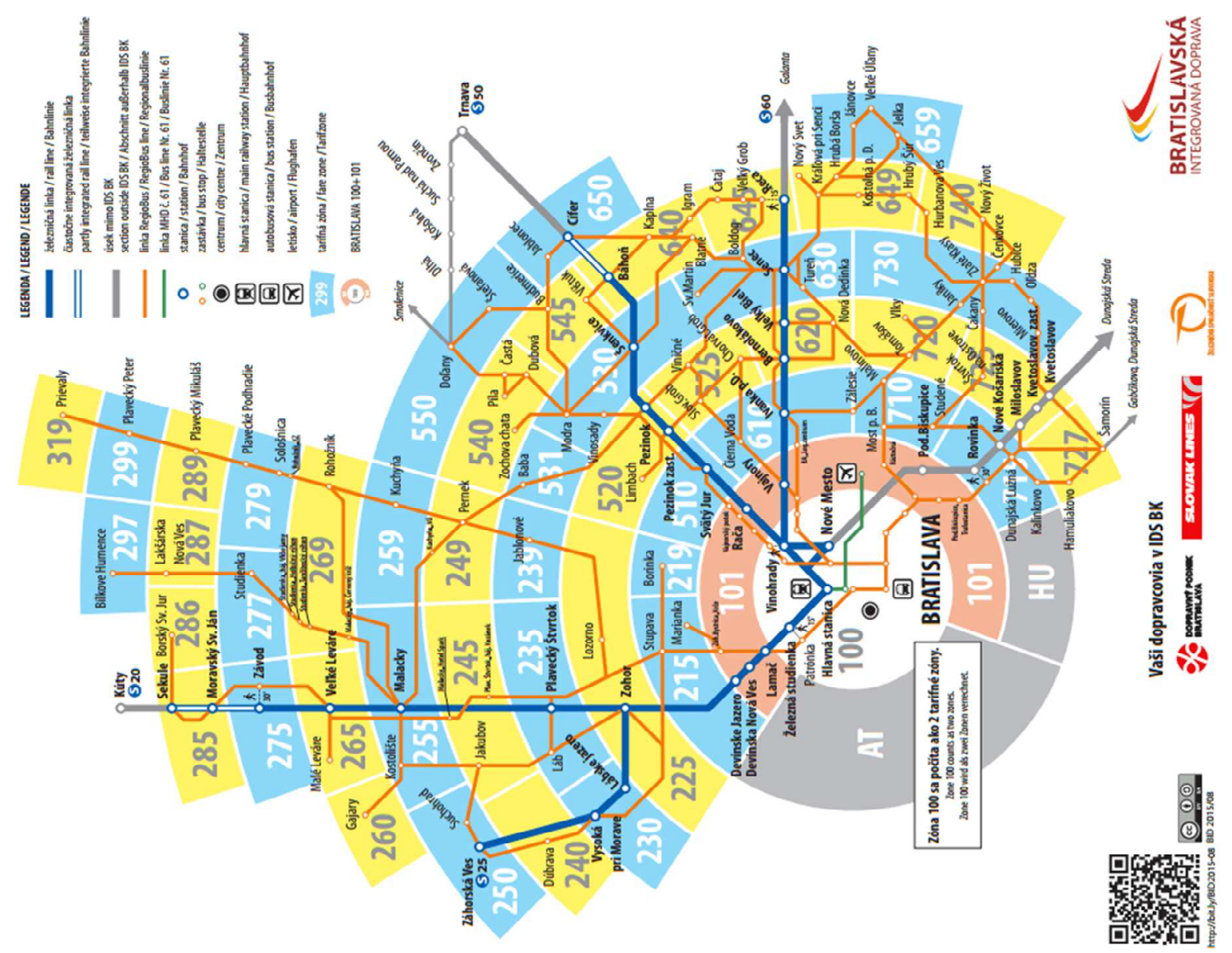

6. Range of BID tariff zones, source: [4], state on 1.10.2016 r.

The integrated tariff system operates:

- 4 regional railway lines (S20, S25, S50, S60),

- 9 tram lines in Bratislava,

- 82 bus and trolleybus lines,

- 50 lines of regional bus transport.

The toll is dependent on the number of "ring segments", i.e. individual zones. There are 12 types of one-off tickets, with a limited period of validity:

- 15 minute or 30 minute tickets for 2 zones or Bratislava (zones 100+101),

- Tickets for 3, 4, 5, 6, 7, 8, 9 or 10 zones (valid from 60 to 150 minutes, depending on the number of zones),

- 3-hour network ticket,

- 24-hour network ticket.

Seasonal tickets are available in variants of 7, 30, 90 and 365 days. Fees depend on the number of zones defined on the ticket and whether the passenger uses public transport in one or two zones in Bratislava. In addition, in order to complete the offer in the city of Bratislava, there are tickets valid only in the zones 100 and 101 (the city of Bratislava) in version 60 
minutes (equivalent to a ticket for 3 zones, 60 minutes), 24 hours, 72 hours ( 3 days) and 168 hours (7 days).

The Bratislava system is similar to the Prague system, with a slightly different configuration of tariff zones. As in the case of the previously discussed systems, the charging tariff is simple and user-friendly and does not include "small print" information and exceptions. In contrast to the Prague system, there are periodic tickets available also in public transport in the city of Bratislava.

\section{The zone system - Paris (Île-de-France)}

Transport system in the area around Paris agglomeration Île-de-France $\left(12012 \mathrm{~km}^{2}\right.$, as mazowieckie province - $35558 \mathrm{~km}^{2}$ ) includes communication:

- by bus,

- by tram,

- by train (RER and SNCF),

- by metro,

organized by the RATP (Régie autonome des transports parisiens - Autonomous management of the Paris transport).

The area is divided into 5 tariff zones, of which the central zone 1 is the city of Paris. There are several types of integrated tariff offers a different range and scope of the validity:

- "T +" tickets - in Paris (Zone 1) single tickets are available "T+" allowing one trip with a change and interval of 90 or 120 minutes, depending on the combination of means of transport. They are valid on buses, trams, metro, and RER suburban trains, and are not honored on SNCF trains,

- "Origine-Destination" ticket - one-way ticket between two arbitrary points of the transport network, valid for all modes of transport (also on SNCF trains),

- Ticket "Paris Visit", on the duration of 1, 2, 3 or 5 days, valid in zones 1 - 3 (Paris Center version ) or 1-5 (Paris Banlieue version), entitling to travel by all means of transport within these zones, also dedicated bus routes to the airport); This ticket is dedicated primarily to tourists but also to business travelers for a short period of time,

- "Mobilis" ticket, one-day ticket valid for all modes of transport in zones 1-2, 1-3, 1-4, $1-5$. The ticket is for people traveling to Paris.

- "Navigo" ticket, weekly, monthly or annual ticket, valid for all means of transport, in variants applicable to zones: 1-2, 1-3, 1-4, 1-5, 2-4, 2-5, 3-5, 2-3, 3-4, 4-5. 


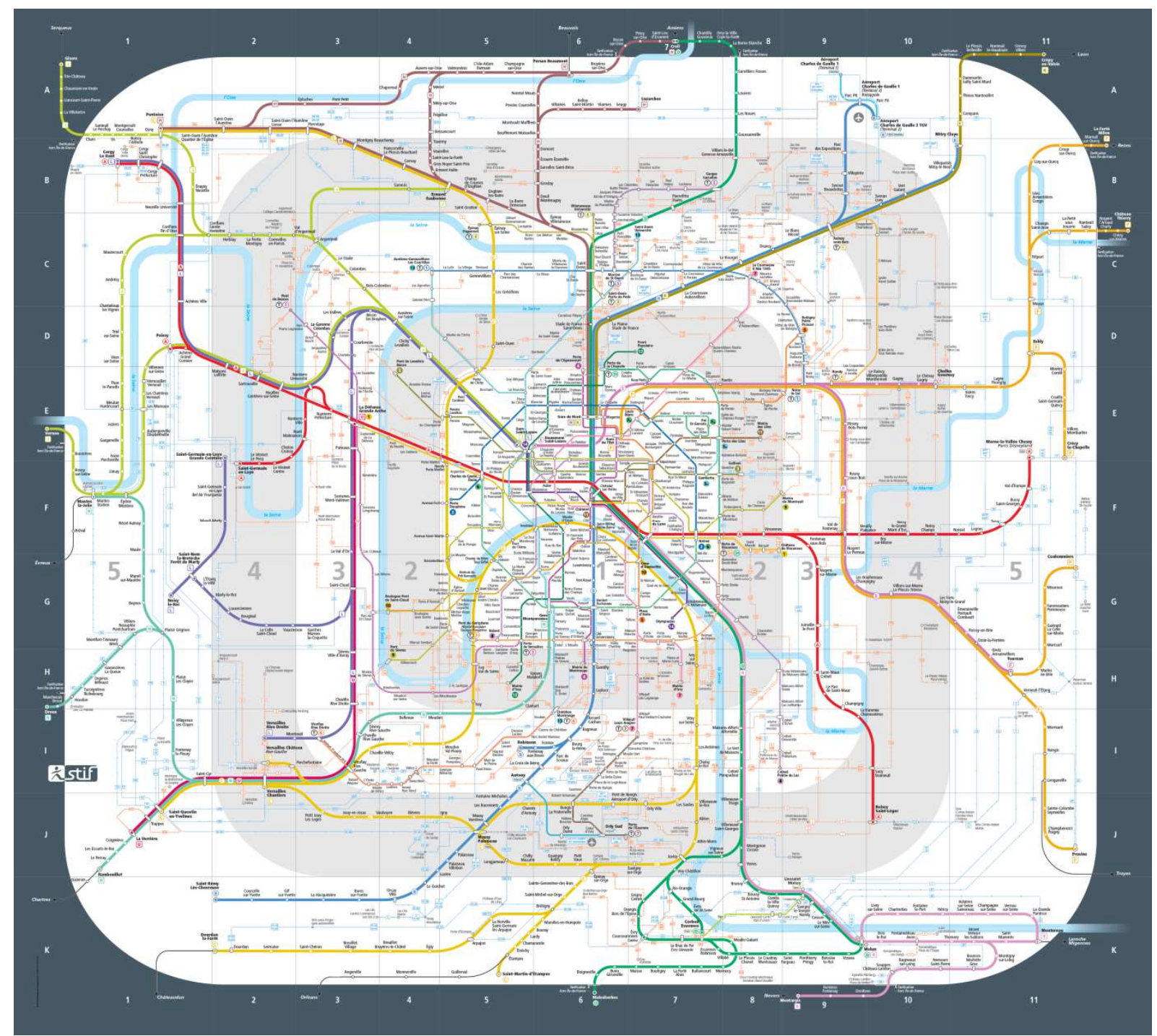

7. Range of tariff zones RATP, source: [8], state on 1.10.2016 r.

\section{Summary and conclusions}

It is impossible to quote all the examples of tariff systems in force in Poland, as in Europe, so 4 different examples of slightly differing tariff systems were chosen. After reviewing the offer of analyzed systems, there are many conclusions about the current state of tariff integration in Poland and the work to be done to implement systems that could be compared with their European counterparts in Central and Western Europe. Three examples from the Czech Republic and Slovakia have been cited, which are mentally and organisationally unlikely to be so distant from Poland as Western Europe.

The first, most important conclusion that follows from the analysis of Polish and foreign tariff systems is that in Poland there is no de facto single comprehensive tariff system that covers more than one city with adjacent suburban areas and includes more means of transport than railway and public transport. Such systems already exist on a large scale in the Czech Republic and Slovakia, i.e. the closest neighbors in Poland.

In Poland, there is no systemic approach to organizing public transport in the provinces (despite the obligation to prepare so-called transport plans). In practice there is a principle that can be summed up by saying "every one of us grafts starch", organizing transport within their own municipality, county, province, regardless of any connection between them.

The problem in the organization of integrated transport systems in Poland may be that most bus services in the provinces operate on a commercial basis, whereas those with subsidized 
self-government authorities are not related in any way (except for the fact that the documentation rests in one drawer or binder in the appropriate office). In individual provinces, there are areas where there is no public transport, so there is no possibility of integrating something that does not exist (similarly, as in many regions it does not reach the rail transport). Even the best tariff system will not meet expectations, if the nearest public transport stop, in which the tariff is valid will have to travel a lot (several dozens) kilometers. For example, in the Czech Republic or in Slovakia, virtually all of the country is covered by regular public bus services that are linked to rail transport.

Tariff integration is only one of the planes of the integrated transport system. Together with it must go hand in hand to ensure the appropriate level of transport offer together with the integration of timetables of individual means of transport - routing of communication lines using interchanges with special attention to communication. Even the most perfect tariff of charges without the right offer of connections will remain only a dead, useless recipe.

Occurring in Poland examples of partial integration of tariffs should still be considered a positive step forward, even though it really available to them in practice is only part of the country's population inhabiting the largest agglomerations. The whole remaining area of the country should be called "tariff Poland B". The consequence of this is the choice of a car as the basic and necessary for the basic life needs of a means of transport, often because of lack of alternatives.

\section{Source materials}

[1] Badanie preferencji i zachowań komunikacyjnych mieszkańców aglomeracji Bydgosko - Toruńskiej, TRAKO, 2010

[2] Badanie preferencji komunikacyjnych mieszkańców Mławy, Z.D.G. TOR, 2014

[3] Badanie zachowań i preferencji komunikacyjnych mieszkańców Olsztyna - główne wyniki badania, Sopot-Warszawa, P.B.S. DGA sp. z o. o., lipiec 2006 r.

[4] Bratislavská integrovaná doprava, a.s., koordinátor IDS BK, www.idsbk.sk

[5] Mazur M., Pojęcie systemu i rygory jego stosowania, Postępy Cybernetyki, z. 2, 1987.

[6] Plan zrównoważonego rozwoju publicznego transportu zbiorowego na lata 2014-2020 dla miasta Rzeszowa i gmin ościennych które zawarły z gminą Miasto Rzeszów porozumienia w zakresie organizacji transportu publicznego, Rzeszów $2014 \mathrm{r}$.

[7] Preferencje i zachowania komunikacyjne mieszkańców Gdyni w 2010 r., ZKM Gdynia, 2010 r.

[8] Régie autonome des transports parisiens - strona internetowa www.ratp.fr,

[9] Regionální organizátor Pražské integrované dopravy, www.ropid.cz,

[10] Słownik języka polskiego pod red. W. Doroszewskiego

[11] Słownik języka polskiego PWN, sjp.pwn.pl

[12] Wyszomirski O., Transport Miejski, ekonomika i organizacja, Wydawnictwo Uniwersytetu Gdańskiego, Gdańsk 2008r. 